\title{
PSYCHOMETRIC PARAMETERS OF AWKWARD MOMENTS TEST FOR SLOVAK POPULATION
}

\author{
Eva BALLOVÁ MIKUŠKOVÁ \\ Institute of Experimental Psychology, Slovak Academy of Sciences \\ Dúbravská cesta 9, 81364 Bratislava, Slovak Republic \\ E-mail: expsebal@savba.sk
}

\begin{abstract}
The Awkward Moments Test maps understanding of other's minds in older children and the aim of this study phase was to verify its psychometric parameters (in Slovak population). Participants were elementary school pupils $(n=312)$ between 10.58 and 15.92 years of age. AMT was administrated together with Imposing Memory Task and Basic Empathy Scale. Results show that 1) AMT has high inter-rater reliability (Intra-class correlation range from 0.985 to 1), 2) the internal consistency of AMT questions was verified (Cronbach's Alpha range from 0.590 to $0.787), 3$ ) there were no correlations among mind-reading items in AMT, IMT and BES, 4) girls were significantly better than boys in mind-reading, and 5) age differences in mind-reading were found only for children up to 12 years. The conclusion is that the Slovak version of AMT is up to standards and can be used in practice (respecting recommendations on the AMT instructions).
\end{abstract}

Key words: AMT, psychometric parameters, internal consistency, inter-rater reliability

Theory of mind, understanding of mind, mindreading - these concepts seem to be mysterious and unclear for the wide public and even among scientists there is a lack of consensus about the content of such concepts. Based on three main theories, Mitchell's model of domain-specific social cognitions (Mitchell, 2006), Adolphs' model

\footnotetext{
Acknowledgement: This research was supported by a grant from the Scientific Agency of Ministry of Education - VEGA No. 1/0541/09 "Interactional strategies of children in context of empathy and cognitions in the perspective of theory of mind" given to Vladimíra Čavojová. We would like to thank Vladimíra Čavojová and Zuzana Belovičová for consultations and constructive comments, Zuzana Sapietová, Marcela Verešová, Martina Romanová, Martin Štulrajter for help with data collection, and principals and students at the elementary schools in Nitra, and Žilina for their participation in the study.
}

of social cognitions (Adolphs, 2006) and Apperly's cognitive dual-system (Apperly, 2011), we can say that theory of mind or mindreading is "...the knowledge, that other people have inner mental states, such as beliefs, desires, intentions (...), and that behavior of others can be explained and predicted on the basis of these mental states" (Čavojová, 2011, p. 19). For the purpose of this study we used the terms theory of mind and mindreading as equivalents.

Research of mindreading (e.g., Apperly, 2011; Astington, Edward, 2010; Ensink, Mayes, 2010; Premac, 1990; Tomasselo, 1995) focused primarily on determining the age when children understand the mind of others (age of $3-5$ years). There is a lack of mindreading studies in children older than 7 years, or even in adults (e.g., Ensink, Mayes, 2010; Epley et al., 2004; Nilsen, Graham, 2009)

DOI: $10.21909 /$ sp.2013.02.632 
because of poorly developed instruments for measuring the theory of mind in older age (7 and above years) and the opinion of some researchers that mindreading development reached its ceiling at the age of 7 years.

The methodology for mapping the theory of mind (especially false belief tasks as a criterion for mindreading) is subject to criticism. Research of mind-reading has been focused primarily on determining the age when children understand the mind of others and not on ages beyond that limit (with few exceptions), even though development of any cognitive ability is not completed at the moment when this ability first occurs (Apperly, 2011; Happé, 1994) and plays an important role throughout life because it is related to human social functioning (Repacholi, Slaughter, 2003). Therefore, many researchers devised theory of mind tests, which were more sensitive to capturing the understanding of mind in others (Heavey et al., 2000).

Classic methods of mapping the theory of mind in children are false belief tasks (tasks measuring the ability to recognize that others can have beliefs about the world that differ from mine). False belief tasks have a great disadvantage in the ceiling effect, represented by the tasks' poor ability to discriminate among children above $7-8$ years (Repacholi, Slaughter, 2003). To eliminate the ceiling effect, it is important to focus on creating tasks which would map the understanding of mind in older children and adults. A simple way would be creating tasks with increased orders of intentionality, i.e., false belief tasks of third and higher order.

Another alternative to avoid the ceiling effect is using more advanced theory of mind tests. In the Awkward Moments Test (AMT) devised by Heavey et al. (2000) “....social understanding was tested using dynamic, fast-paced stimuli, depicting real people in real-life contexts, requiring the processing of subtle, transient cues" (Heavey et al., 2000, p. 226). Authors of AMT assume that the sensitivity of the tasks can increase by using a naturalistic test format. We consider AMT as appropriate for mapping the mindreading in older children and we decided to verify its psychometric parameters for the Slovak population.

The process of AMT adaptation for the Slovak population (Ballová Mikušková, Belovičová, Čavojová, 2011) consisted of five steps: a) selection of short film previews; b) compilation of a test-sheet with one control and two test questions, which took a form of open questions; c) administration of films to a sample of participants (sample 1), in order to collect free responses; d) processing of free responses; e) compilation of four alternative responses for one control and one test question according to the system from Bosacki and Astington (1999).

The rationale for this paper is the verification of psychometric parameters of AMT (Slovak version). We focused on the verification of a) inter-rater reliability - agreement among raters, b) internal consistency of all three AMT questions and c) validity of Mindreading question. Finally, we focused on gender and age differences among children in mindreading.

To summarize, we formulated three interrelated research questions (1-3) and two hypotheses (4-5). We asked: 1) How high will be the level of agreement in the Mindreading question among raters before and after the reciprocal consultation? In the original study, participants answered the Mindreading question verbally. In our study, participants wrote down their responses, so their quality may be influenced by the ability of the children 
to express themselves in writing. This question was rated by three raters requiring the evaluation of agreement among raters (interrater reliability). On the other hand, agreement among raters enabled us to verify the difficulty of the evaluation process.

Our second question was: 2) Does the internal consistency of AMT reach at least the level of 0.7 ? Internal consistency measured by Cronbach's alpha ranges between zero and one and a commonly accepted value for acceptable internal consistency is 0.7 and more (George, Mallery, 2003). We were interested if Cronbach's alpha of the questions will be above this level. Finally, we asked: 3) What aspects of the mindreading will the Mindreading question capture? We verified the correlation of the Mindreading question with selected subscales in Imposing Memory Task and Basic Empathy Scale that map different theory of mind aspects (the subscale Theory of Mind in IMT captures the ability to understand others' expectations, beliefs and intentions and the subscale Cognitive Empathy in BES captures the ability to understand another's feelings).

Some researchers (e.g., Russell et al., 2007) found that there are no clear gender differences in mindreading. But there is a social presumption that women are better than men in attributing mental states and in responding to affective states of others. And it appears that gender differences lie in the social-cognitive functioning, how men and women think and solve social and interpersonal conflicts (Walker, 2005). We supposed: 4) that there will be differences between girls and boys in the theory of mind (measured by Mindreading question in AMT).

Finally, we supposed: 5) that older children would perform better in the Mindreading question (AMT) than younger children. As other cognitive skills, so does mindreading ability increase with age (and according to Charlton et al., 2009, from a certain age mindreading ability declined, as other cognitive skills).

\section{METHODS}

\section{Participants}

Participants were 312 elementary school pupils (161 boys and 151 girls) from three schools (two from Nitra, one from Žilina) between 10.58 and 15.92 years of age $(M=$ 13.26, $\mathrm{SD}=1.37)$. Participants were divided into two samples, according to the time of data collection. Sample 1 consisted of 246 pupils from two schools in Nitra (127 boys, 119 girls) between 10.58 and 15.92 years of age $(\mathrm{M}=13.20, \mathrm{SD}=1.51)$ and sample 2 consisted of 66 pupils from one school in Žilina (34 boys, 32 girls) between 12.17 and 14.33 years of age $(\mathrm{M}=13.50, \mathrm{SD}=0.53$; descriptive statistics in Table 1). Permission was obtained from principals of the respective schools for data collection during school times.

\section{Procedure}

Data were collected in two sessions: in one session empathy questionnaires (Basic Empathy Scale, Interpersonal Reactivity Index) were administered by local teachers, in the second session sociometric questionnaire together with mindreading tests (Awkward Moments Test, Imposing Memory Task) were collected by two researchers with whom the children were not familiar.

Tests were administered in the same order to each participant and one session lasted 45 minutes (one school period). First, we 
administrated tests to participants from Nitra (first version of AMT), and next to participants from Žilina (AMT - version for Slovak population).

\section{Measures}

Awkward Moments Test: The original version of AMT (Heavey et al., 2000) comprised eight short films. In our version we had six films (advertising shots, as in the British version, with high technical quality and complete storyline).

The first film was used as a practice task in both versions. Following films ${ }^{1}$ constituted the test stimuli. The stories took place in a variety of situations (domestic/home settings, a restaurant, a camping site, a garden)

\footnotetext{
${ }^{1}$ Film 2 "Leaving home" - son moves out from his parents' house, he and his parents pretended sadness when saying goodbye, but when the door closed behind the son, he and his parents rejoiced. Film 3 "Bobika" - a wealthy lady came to a Chinese restaurant with her dog and she said to a waiter: "Take care of Bobika". When the waiter served the food, he said: "Bobika!". Film 4 "Surprise" - a man driving a car that transports concrete came home and he saw a new car in front of his house and through the window he saw his wife in the embrace of strange man. In anger he poured concrete into the new car. Then he saw the stranger giving the prize to his wife keys to a new car. Film 5 "Friends" - around the campfire friends shared a bottle of coke (and singing a song about friendship), one of them is a green alien who drooled into the bottle and gave it to another guy who paused and wanted to wipe the neck of the bottle. All friends stopped singing and looked at him, then he smiled and drank from the drooled-in bottle. Film 6 "Visit" - parents came to visit their daughter and her husband, when they entered the flat they saw plastic sheets everywhere and red patches on the walls; parents seemed scared, until they found out that the young husband was painting the flat.
}

both in Slovak and international locations. Characters were of different ages (from teenagers to elderly people) and actors were depicted in various roles and relationships (friends, neighbors, lovers, and work colleagues). Films showed characters in awkward or socially embarrassing situations. Films were projected on a screen placed on the wall before the pupils and responses were recorded on the answer sheet. Administration of AMT lasted 20 minutes.

Each film was followed by three questions: 1) Control question (CQ, mapping memory and attention, for example: What did the friends drink around the fire?) refers to directly observable information from the film, 2) Emotional question (EQ, mapping correct recognition of target character's emotion, for example: How did parents feel at the end of the video?) and 3) Mindreading question (MQ, mapping the inferring of intention of the character, for example: Why did the man pour concrete into the blue car?) - to answer this question correctly it is necessary to assess beliefs and characters of actors and also social significance of the character's actions. CQ and EQ are closed question with four one-word answers, MQ is an open question. Although we studied all three questions, the greatest emphasis was placed on MQ (primary aim of the study).

Scoring of the Slovak version is based on assigning 1 for correct and 0 for incorrect response in questions CQ and EQ. Scoring of question MQ is based on Bosacki and Astington's system (1999): 0 for the response "I don't know" or for an evasive answer; 1 for the response describing the behavior of the characters, for example, "The son leaves the house"; 2 for the response describing the mental state of the characters, for example, "They pretended to be sad"; 
3 for the response involving two or more mental states of the characters grouped together in a coherent way and/or taking into account the cultural norms, conventions and ethical rules, for example, "They behaved as if they were sad, because they didn't want to offend one another, but really they were happy that they will be alone. They had to pretend to be sad, because it is not polite to be happy, when your son leaves and you don't want your neighbors to see it". In this question the best responses of participants were rated.

In the original version the question MQ was administrated as an interview and the participants' total scores were rated by two raters (high inter-rater reliability, Intra-class correlation of 0.99; Heavey et al., 2000). In our version it took a written form as an open question and participants' total scores were rated by three raters (more raters could perceive a wider range of issues and ambiguities in the rating). Raters were one man and two women; all three had experience with qualitative evaluation of data and with content analysis (rater 1 and 3 - women, 7 years of practice; rater $2-$ man, 11 years of practice). Ratings were made in three steps: 1) independent ratings of participants' answers; 2) comparison of ratings and consultation about disagreements and controversial responses; 3) ratings of participants' answers according to the conclusion of consultations. Finally, for each participant the average score of MQ from the ratings in step 3 were calculated.

Imposing Memory Task: The IMT (Kindermann, Dunbar, Bentall, 1998) assesses the mentalizing ability. The IMT featured a series of five stories that were read aloud to the participants at the same time as being presented via computer projection.
Four of these stories involved complex social situations that required listeners to understand various intentions and perspectives of the actors (such as complicated love affairs or attempt to deceive the boss to gain a pay rise). The fifth story was the "control" as it involved only one actor and chain of causal events (the old man who unfortunately burnt himself in his sleep with a cigarette). Children answered memory questions presented in a booklet and they had to choose between two alternative options, one correct and one incorrect. Questions either concerned theory of mind elements in the stories (the Theory of Mind variable (ToM) the expectations or beliefs of participants about the actor's intentional state; from firstorder to fifth-order questions) or they were memory questions (the Memory variable). Participants could gain 1 for correct and 0 for incorrect response. The scores could range from 0 indicating low level of theory of mind to 40 indicating high level of theory of mind. We took into account only the score of the subscale Theory of Mind in correlation with Mindreading Question in AMT.

Basic Empathy Scale: We used the Slovak adaptation (Čavojová, Sirota, Belovičová, 2012) of the BES (Jolliffe, Farrington, 2006), which was back-translated by two psychologists and then modifications were made in panel review with the whole research team. It consists of two subscales detecting two different components of empathic responsiveness: the subscale Affective Empathy (AE) measuring emotional congruence with another person's emotions, and the subscale Cognitive Empathy (CE) measuring ability to understand another person's emotions. Responses were made on a fivepoint Likert scale ranging from "strongly disagree (1)" to "strongly agree (5)". Scores 
could range from 9 to 45 points for Cognitive empathy; from 11 to 55 for Affective empathy. We took into account only the score of the subscale Cognitive Empathy in correlation with Mindreading question in AMT.

\section{RESULTS}

\section{Analysis Overview}

As the first step in the analysis we provide descriptive statistics, and then inter-rater reliability by single measure intra-class correlation (Intra-class correlation coefficient; sample 1) and internal consistency of AMT questions (Cronbach's alpha; sample 2) were calculated. In the next step, the correlations of Mindreading question with other study variables (Theory of Mind and Cognitive Empathy; total sample) were calculated. Finally, gender and age differences in all three questions of AMT were calculated (total sample). Data were processed by statistical program IBM SPSS V20.

Table 1. Descriptive statistics of the samples

\begin{tabular}{|c|c|c|c|c|c|}
\hline & Total & Boys & Girls & Sample 1 & Sample 2 \\
\hline $\mathrm{N}$ & 312 & 161 & 151 & 246 & 66 \\
\hline \multicolumn{6}{|l|}{ Age } \\
\hline$M$ & 13.26 & 13.39 & 13.13 & 13.20 & 13.50 \\
\hline$S D$ & 1.37 & 1.37 & 1.36 & 1.51 & 0.53 \\
\hline \multicolumn{6}{|l|}{ AMT } \\
\hline \multicolumn{6}{|c|}{ Control question } \\
\hline$M$ & 4.48 & 4.37 & 4.61 & 4.45 & 4.49 \\
\hline$S D$ & 0.84 & 1.02 & 0.59 & 0.95 & 0.82 \\
\hline \multicolumn{6}{|c|}{ Emotional question } \\
\hline$M$ & 2.14 & 1.98 & 2.31 & 4.74 & 1.44 \\
\hline$S D$ & 1.61 & 1.64 & 1.55 & 0.81 & 0.89 \\
\hline \multicolumn{6}{|c|}{ Mindreading question } \\
\hline$M$ & 7.92 & 7.34 & 8.54 & 9.48 & 7.50 \\
\hline$S D$ & 2.70 & 2.96 & 2.24 & 2.53 & 2.60 \\
\hline \multicolumn{6}{|l|}{ IMT } \\
\hline \multicolumn{6}{|c|}{ Theory of Mind } \\
\hline$M$ & 34.64 & 33.60 & 35.78 & 36.26 & 34.14 \\
\hline$S D$ & 4.94 & 5.13 & 4.46 & 4.21 & 5.04 \\
\hline \multicolumn{6}{|l|}{ BES } \\
\hline \multicolumn{6}{|c|}{ Cognitive Empathy } \\
\hline$M$ & 12.32 & 11.99 & 12.68 & 13.02 & 12.15 \\
\hline$S D$ & 1.86 & 1.95 & 1.68 & 1.62 & 1.87 \\
\hline
\end{tabular}

Note: AMT - Awkward Moments Test; IMT - Imposing Memory Task; BES - Basic Empathy Scale; Sample 1 - pupils from two Nitra schools; Sample 2 - pupils from Žilina school 


\section{Descriptive Statistics}

Descriptive statistics of children is shown in Table 1 (average and standard deviation of the main variables in the total sample, separately for sample 1 and sample 2 , and for boys and girls). Gender and age differences were tested for statistical significance (hereinafter).

\section{Inter-Rater Reliability of Mindreading Question (AMT)}

Inter-rater reliability in Mindreading question was verified on sample $1(n=246)$, as the competition of first phase of AMT adaptation. This procedure was done in three steps. First, raters assessed MQ just according to the written instructions (without consulting with each other). The agreement among three raters (all three rates gave the same rating) ranged from $33.2 \%$, Intra-class correlation of 0.461 for the film "Friends" to $86.1 \%$, Intra-class correlation of 0.931 for the film "Surprise".

In the second step, raters consulted each other's rankings and also how they understood the instructions. In the third step, raters assessed MQ again according to the conclusions of consultations. The agreement among three raters increased: it ranged from $93.82 \%$, Intra-class correlation of 0.985 for the film "Friends" to $100 \%$, Intra-class correlation of 1 for the film "Surprise". This indicated a high level of inter-rater reliability (Table 2).

Also differences among raters were calculated, separately in the first and in the second rating of MQ. In the first rating, differences among raters were significant (there was an exception: non-significant differences

Table 2. Inter-rater reliability: The agreement among three raters (first and second assessment)

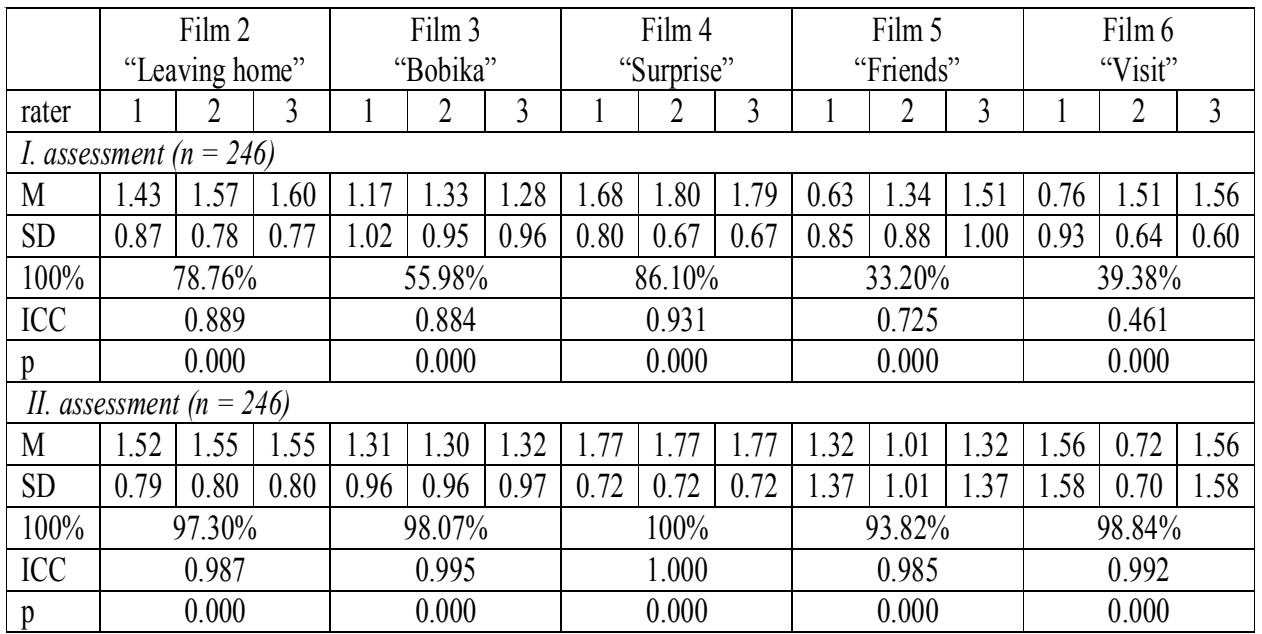

Note: M - mean, SD - standard deviation, 100\% - absolute agreement among raters (\%), ICC - Intra-class correlation coefficient (absolute agreement), $\mathrm{p}$ - significance of ICC 
between rater 2 and rater 3 in item $2: \mathrm{t}=$ $-1.236 ; \mathrm{p}=0.128$, in item $3: \mathrm{t}=0.895 ; \mathrm{p}=$ 0.372 ), in item $4: t=0.426 ; p=0.671)$. In the second rating, differences among raters were non-significant (there was an exception: significant difference between rater 1 and rater 2 in item 5: $\mathrm{t}=-2.679 ; \mathrm{p}=0.008$; and significant difference between rater 1 and rater 3 in item 5: $\mathrm{t}=3.032 ; \mathrm{p}=0.003$ ).

\section{Internal Consistency of AMT Questions}

Internal consistency of AMT was verified on sample $2(n=66)$. For the Control question Cronbach's alpha was 0.576 (if item 4 was deleted, Cronbach's alpha would increase to 0.585). For Emotional question Cronbach's alpha was 0.787 and Emotional question appeared problematic in one item: if item 4 was deleted, Cronbach's alpha would increase to 0.853 . For Mindreading question Cronbach's alpha was 0.590 and if item 2 was deleted, Cronbach's alpha would increase to 0.615 .

\section{Bivariate Correlations}

We correlated Mindreading question (AMT) with two variables, the subscale Cog- nitive Empathy from BES and the subscale Theory of Mind from IMT in total the sample $(\mathrm{n}=312)$. Correlations were too weak: Mindreading question had weak correlation with Theory of Mind from IMT $(r=0.214$, significance at the 0.01 level) and correlation with Cognitive Empathy from BES was close to zero $(r=0.035, \mathrm{~ns}$. $)$.

\section{Gender and Age Differences}

Gender and age differences in each question of AMT were verified in the total sample $(\mathrm{n}=312)$. Girls, in comparison to boys, obtained higher scores in all three questions. Differences between boys and girls were significant (Table 3$)$ in the Control question $(\mathrm{t}=$ $-2.560, \mathrm{p}=0.011)$ and in the Mindreading question $(\mathrm{t}=-4.015, \mathrm{p}=0.000)$. In the Emotional question differences were non-significant $(\mathrm{t}=-1.820, \mathrm{p}=0.070)$.

We also examined age differences. First, we divided participants into two groups, younger and older children, according to the median (13.67 years). Under this condition, we found non-significant differences in all three questions (for Control question: $\mathrm{t}=$ $-0.929, \mathrm{p}=0.354$; for Emotional question $\mathrm{t}=$ $-0.749, p=0.454$; for Mindreading question

Table 3. Gender differences in AMT

\begin{tabular}{|c|c|c|c|c|c|c|}
\hline & $\mathrm{N}$ & $\mathrm{M}$ & $\mathrm{SD}$ & $\mathrm{t}$ & $\mathrm{p}$ & df \\
\hline \multicolumn{7}{|c|}{ Control question } \\
\hline boys & 161 & 4.37 & 1.02 & \multirow{2}{*}{-2.560} & \multirow{2}{*}{0.011} & \multirow{2}{*}{310.00} \\
\hline girls & 151 & 4.61 & 0.59 & & & \\
\hline \multicolumn{7}{|c|}{ Emotional question } \\
\hline boys & 161 & 1.98 & 1.64 & \multirow{2}{*}{-1.820} & \multirow{2}{*}{0.070} & \multirow{2}{*}{310.00} \\
\hline girls & 151 & 2.31 & 1.55 & & & \\
\hline \multicolumn{7}{|c|}{ Mindreading question } \\
\hline boys & 161 & 7.34 & 2.96 & \multirow{2}{*}{-4.015} & \multirow{2}{*}{0.000} & \multirow{2}{*}{310.00} \\
\hline girls & 151 & 8.54 & 2.24 & & & \\
\hline
\end{tabular}


Table 4. Age differences in AMT

\begin{tabular}{|c|c|c|c|c|c|c|c|c|}
\hline \multicolumn{4}{|c|}{ Control question } & \multicolumn{5}{|c|}{ ANOVA (between groups) } \\
\hline & $\mathrm{N}$ & M & $\mathrm{SD}$ & $\begin{array}{l}\text { Sum of } \\
\text { Squares }\end{array}$ & df & $\begin{array}{l}\text { Mean } \\
\text { Square }\end{array}$ & $\mathrm{F}$ & $\mathrm{p}$ \\
\hline $10-12$ years & 69 & 4.48 & 0.92 & \multirow{3}{*}{1.598} & \multirow{3}{*}{2} & \multirow{3}{*}{0.799} & \multirow{3}{*}{1.118} & \multirow{3}{*}{0.328} \\
\hline $12-14$ years & 136 & 4.41 & 0.80 & & & & & \\
\hline $\begin{array}{l}14 \text { and more } \\
\text { years }\end{array}$ & 106 & 4.58 & 0.85 & & & & & \\
\hline \multicolumn{9}{|c|}{ Emotional question } \\
\hline $10-12$ years & 69 & 1.25 & 0.65 & \multirow{3}{*}{85.381} & \multirow{3}{*}{2} & \multirow{3}{*}{42.691} & \multirow{3}{*}{18.566} & \multirow{3}{*}{0.000} \\
\hline $12-14$ years & 136 & 2.61 & 1.82 & & & & & \\
\hline $\begin{array}{l}14 \text { and more } \\
\text { years }\end{array}$ & 106 & 2.09 & 1.49 & & & & & \\
\hline \multicolumn{9}{|c|}{ Mindreading question } \\
\hline $10-12$ years & 69 & 6.91 & 2.97 & \multirow{3}{*}{90.423} & \multirow{3}{*}{2} & \multirow{3}{*}{45.212} & \multirow{3}{*}{6.427} & \multirow{3}{*}{0.002} \\
\hline $12-14$ years & 136 & 8.08 & 2.75 & & & & & \\
\hline $\begin{array}{l}14 \text { and more } \\
\text { years }\end{array}$ & 106 & 8.32 & 2.27 & & & & & \\
\hline
\end{tabular}

$t=-1.611, p=0.108)$. These results did not correspond either to our assumption, or to findings of other studies. Therefore, we decided to divide participants into three groups (according to a more sensitive two-year interval: 10-12 years, 12-14 years, 14 and more years).

One-way analysis of variance (ANOVA) was used to calculate differences among three age groups. We found non-significant differences in the Control questions and significant differences in the Emotional and Mindreading questions (Table 4). In the Emotional question there were significant differences between a) group " $10-12$ years" and "12-14 years" $(\mathrm{p}<0.001 ; 95 \% \mathrm{CI}=0.923$ 1.805 ) and b) group " $10-12$ years" and " 14 and more years" ( $\mathrm{p}<0.001 ; 95 \% \mathrm{CI}=0.386$ 1.309). Also in Mindreading question there were significant differences between a) group "10-12 years" and "12-14 years" $(p=0.003 ; 95 \% \mathrm{CI}=0.396-1.939)$ and $b)$ group
"10-12 years" and " 14 and more years" ( $\mathrm{p}=$ $0.001 ; 95 \% \mathrm{CI}=0.600-2.215$ ).

\section{DISCUSSION}

One of the biggest disadvantages of theory of mind tests is the ceiling effect. Therefore, researchers began constructing theory of mind tests which were more sensitive to capture the mindreading in others, both in children and adults. One such test is the Awkward Moments Test (AMT) by Heavey et al. (2000). The aim of this study was to verify psychometric parameters of AMT, in other words, to verify the usability of AMT for Slovak population. In the current study, we focused on the inter-rater reliability (agreement among raters), the internal consistency, aspects of theory of mind that are captured by Mindreading question, and on the gender and age differences among children in AMT. 


\section{Inter-Rater Reliability of Mindreading Question}

The first aim of this study was the verification of inter-rater reliability of ratings in Mindreading question (AMT), in other words, we focused on the agreement in ratings of MQ among three raters. When raters assessed answers only according to instructions, without consultations, they achieved weak agreement (significant differences among raters). In the next step, raters consulted their findings and also how they understand the instructions. After this consultation, they rated all answers again and achieved agreement close to absolute agreement (93.82 - 100\%; an absolute agreement was in one item). In other words, MQ achieved high inter-rater reliability.

On one hand, we verified a high inter-rater reliability of Mindreading question, but on the other hand, we uncovered weaknesses of the instructions for ratings. The consultations among raters were beneficial, because they showed that raters understood the same instructions (how to score answers) in different ways. Different ratings of the same answers (before consultations) were caused by the systematic errors of raters (inaccurate reading of instructions, incorrect understanding of instructions) in some items which were either underrated or overrated. For example, rater 1 scored only explicitly written answers. Other two raters were more benevolent if a missing word or phrase was in the answer (apparently some children thought faster than they wrote); they scored it as a complete answer. During consultations raters agreed that they would accept the incomplete answers when it was obviously caused by quick writing (missing one word for example) and the answer was meaningful, despite the missing word(s).

Systematic errors of raters were caused by ambiguities and problematic parts of instructions detected during the consultation. Despite this fact, we consider the instructions as adequate. We propose to add more examples to each instruction that would illustrate the various alternatives of scoring (in the current form each item has only one example of scoring). Also, according to the British original version, an interview after AMT administration could facilitate the rating ofMQ, because participants would specify and complete their answers. If instructions and interview were completed after testing was made, it would not be difficult to learn the rating of Mindreading question.

\section{Internal Consistency of AMT}

Next, we examined the internal consistency of AMT through Cronbach's alpha (whether the internal consistency of AMT was on the level of at least 0.7 ). Mindreading question and Control question had the internal consistency below the level of 0.7 .

Only the Emotional question had the internal consistency at a level of about 0.7 (0.787, and if item 4 was deleted, Cronbach's alpha could increase). In item 4 (film "Surprise") two from four alternative answers to the Emotional question appear correct (Story: The man came to visit a woman, he arrived in a new car. The woman is pleased, they are hugging one another. At that moment her husband gets home. He drives a car with concrete. He sees the whole scene and in anger pours the concrete into the new car. Immediately we learn that the woman won the car and the strange man just gave it to her. Question: "How did the driver feel at 
the end of the movie? Answers: victorious, sleepy, impatient, stupid). An answer stupid was correct, but it was possible that some children so identified with the main character that they transferred their own feeling of victory into the responses. It appears that they did not take into account the final feeling of the actor, but the strongest feeling that the film left in them. According to the results we suggest to change the answer victorious in the Emotional question to wise, so that all four alternative answers are clearer and not interchangeable. (In each question there are four alternative answers: one correct, one contradictory to the correct, one incorrect, and one expressing body feeling. The proposed answer wise is contradictory to the correct answer stupid.)

\section{Mindreading Question and Theory of Mind}

As the third step, we focused on what aspect of the theory of mind does the Mindreading question capture. According to Heavey et al. (2000), Mindreading question in AMT measures the ability to infer the intention of the characters and it is necessary to assess the beliefs and characters of the actors as well as the social significance of the character's actions to answer this question correctly. In our study we correlated MQ with the subscale Cognitive Empathy from BES and subscale Theory of Mind from IMT (all correlation were weak). Relations between MQ, CE and ToM were weak due to the fact, that each subscale measures the theory of mind from a different perspective. The Mindreading question in AMT captures the ability to infer intentions and social consequences of behavior, the subscale Theory of Mind in IMT captures the ability to un- derstand others expectations, beliefs and intentions and the subscale Cognitive Empathy in BES captures the ability to understand another's emotions. Therefore, it is necessary to verify the validity of MQ by other theory of mind tests, which also map the ability to infer intentions of others (and/ or social consequences of other's behavior), for example, The Hinting task (Corcoran, Mercer, Frith, 1995) or The Intention Inference task (Sarfati et al., 1997).

\section{Gender and Age Differences in Mindreading}

Finally, we sought evidence for the hypothesis that there are gender and age differences in mind-reading because there is a well-known assumption about gender differences in social cognition, namely, that women are better than men in attributing mental states and in understanding the minds of others. In the current study, we found evidence for the gender difference hypothesis, girls were better than boys in all three questions of AMT. Although there have been few studies introducing evidence that there are no gender differences in the theory of mind (e.g., Russell et al., 2007), according to the current findings and findings from several others studies (e.g., Walker, 2005; Charman, Health, Ruffman, 2002) we maintain that girls are better than boys in mind-reading and also in understanding emotions of others.

To verify the age differences, we first divided participants into two groups, younger and older children. In this condition, we did not find age differences in AMT questions. Because these findings were inconsistent with the facts that the ability to understand the mind of others increases with age, we divided participants into three groups (by 
two-year interval). In this condition, we found no age differences in the Control question. In Emotional and Mindreading questions there were significant differences: 1) between 10-12 years old and 12-14 years old children and 2) between 10-12 years old and 14 and more years old children. Differences between 12-14 year olds and 14 and more year olds were not confirmed. Can we conclude that the measurement of recognition of other's emotion and measurement of mindreading in AMT have the age ceiling (as well as other tests mentioned in the introduction)? If yes, is the limit for AMT the age of 12 years? Although it is a higher age ceiling than in other theory of mind tests, it still limits AMT only for the use in preadolescent samples. Therefore, it would be useful to make an empirical verification of AMT's availability for age categories higher than 12 years. In such research it would be desirable to increase the number of questions from 6 to 8 (as it is in the British version), with the last two questions being more difficult than the previous to discriminate older, or more mature children.

\section{CONCLUSION}

In the past, most studies of mindreading focused on when, at what age, do children already possess the theory of mind. Now, the trend is to study the extent to which mindreading is developed. Therefore, it is necessary (in research and also in clinical practice) to use instruments that can capture the theory of mind and its level in older children, possibly in adults. We tried to find whether the Slovak version of AMT is suitable for use in practice and whether the AMT really maps mind-reading in older children (as maintained by the authors).
We assume that the AMT had an age limit (12 years) and its verification could be a research challenge, however, our conclusion is that the Slovak version of AMT is up to the standards and can be used in practice (respecting our recommendations on the instructions).

Received June 22, 2012

\section{REFERENCES}

ADOLPHS, R., 2006, How do we know the minds of others? Domain-specificity, simulation, and enactive social cognition. Brain Research, 1079, 1, 25-35. Retrieved from http://www.ncbi.nlm.nih .gov/pubmed/16507301

APPERLY, I., 2011, Mindreaders. The cognitive basis of ,, Theory of Mind“. Hove: Psychology Press. ASTINGTON, J.W., EDWARD, M.J., 2010, The development of Theory of Mind in early childhood. In: R.E. Tremblay, R. Barr (Eds.), Encyclopedia of Early Childhood Development (pp. 1-6). online.

BALLOVÁ MIKUŠKOVÁ, E., BELOVIČOVÁ, Z., ČAVOJOVÁ, V., 2011, Proces adaptácie Heaveyho testu ,Nečakané momenty” na Slovensku (fáza I.). Cesty $k$ múdrosti, 29. Psychologické dni. Kniha abstraktov. Bratislava: Stimul.

BOSACKI, S., ASTINGTON, J.W., 1999, Theory of Mind in preadolescence: Relations between social understanding and social competence. Social Development, 8, 2, 237-255.

CHARLTON, R.A., BARRICK, T.R., MARKUS, H.S., MORRIS, R.G., 2009, Theory of mind associations with other cognitive functions and brain imaging in normal aging. Psychological Aging, 24, 2, 338-348.

CHARMAN, T., HEALTH, C., RUFFMAN, T., 2002, Is there a gender difference in false belief development? Children, 11, 1-10.

CORCORAN, R., MERCER, G., FRITH, C.D., 1995, Schizophrenia, symptomatology and social inference: Investigating "Theory of Mind" in people with schizophrenia. Schizophrenia Research, 17, 5-13.

ČAVOJOVÁ, V., 2011, Čo rozumieme pod teóriou mysle: Predstavenie troch kognitívnych modelov. In: V. Čavojová, E. Ballová Mikušková, Z. Belovičová (Eds.), Chápanie duševných stavov 
$v$ kontexte kognitivneho vývinu (pp. 19-41). Bratislava: ÚEP SAV.

ČAVOJOVÁ, V., SIROTA, M., BELOVIČOVÁ, Z., 2012, Slovak validation of the Basic Empathy Scale in pre-adolescents. Studia Psychologica, 54 3, 195-208

ENSINK, K., MAYES, L.C., 2010, The development of mentalisation in children from a Theory of Mind perspective. Psychoanalytic Inquiry, 30, 301-337.

EPLEY, N., KEYSAR, B., VAN BOVEN, L., GILOVICH, T., 2004, Perspective taking as egocentric anchoring and adjustment. Journal of Personality and Social Psychology, 87, 327-339.

GEORGE, D., MALLERY, P., 2003, SPSS for

Windows step by step: A simple guide and reference. 11.0 update (4th Ed.). Boston: Allyn \& Bacon

HAPPÉ, F.G.E., 1994, An advanced test of Theory of Mind: Understanding of story characters' thoughts and feelings by able autistic, mentally handicapped, and normal children and adults. Journal of Autism and Developmental Disorders, 24, 2, 129-154. doi:10.1007/BF02172093

HEAVEY, L., PHILLIPS, W., BARON-COHEN, S., RUTTER, M., 2000, The Awkward Moments Test: A naturalistic measure of social understanding in autism. Journal of Autism and Developmental Disorders, 30, 3, 225-236. Retrieved from http:// www.ncbi.nlm.nih.gov/pubmed/11055458

JOLLIFFE, D., FARRINGTON, D.P., 2006, Development and validation of the Basic Empathy Scale. Journal of Adolescence, 29, 4, 589-611. doi:10.1016/j.adolescence.2005.08.010

KINDERMANN, P., DUNBAR, R., BENTALL, R.P., 1998, Theory-of-mind deficits and causal at- tributions. British Journal of Psychology, 89, 191204.

MITCHELL, J.P., 2006, Mentalizing and Marr: An information processing approach to the study of social cognition. Brain Research, 1079, 66-75.

NILSEN, E.S., GRAHAM, S.A., 2009, The relations between children's communicated perspectivetaking and executive functioning. Cognitive Psychology, 58, 220-249.

PREMAC, D., 1990, The infant's theory of selfpropelled objects. Cognition, 36, 1-16.

REPACHOLI, B., SLAUGHTER, V., 2003, Individual differences in Theory of Mind: Implication for typical and atypical development. New York and Hove: Psychology Press.

RUSSELL, T.A., TCHANTURIA, K., RAHMAN, Q., SCHMIDT, U., 2007, Sex differences in theory of mind: A male advantage on Happé's "cartoon" task. Cognition \& Emotion, 21, 7, 1554-1564. doi:10.1080/02699930601117096

SARFATI, Y., HARDY-BAYLÉ, M., BESCHE, C., WIDLOCHERR, D., 1997, Attribution of intentions to others in people with schizophrenia: A non-verbal exploration with comic strips. Schizophrenia Research, 25, 199-209.

TOMASSELO, M., 1995, Joint attention as social cognition. In: C. Moore, P. Dunham (Eds.), Joint attention: Its origins and role in development (pp. 103-130). New York: Lawrence Erlbaum Associates.

WALKER, S., 2005, Gender differences in the relationship between young children's peer-related social competence and individual differences in Theory of Mind. The Journal of Genetic Psychology, 166, 3, 297-312. Retrieved from http://eprints .qut.edu.au/2301/1/Gender_differences_Tom.pdf

\section{PSYCHOMETRICKÉ PARAMETRE AWKWARD MOMENTS TEST PRE SLOVENSKÚPOPULÁCIU}

\section{E. B a 110 vá M i ku šková}

Súhrn: AMT (The Awkward Moments Test) mapuje teóriu mysle u detí. Ciel'om štúdie bolo overenie psychometrických parametrov slovenskej verzie AMT. Participantmi boli žiaci základných škôl $(\mathrm{n}=312)$ vo veku 10,58 - 15,92 rokov. Spolu s AMT boli administrované aj IMT (Imposing Memory Task) and BES (Basic Empathy Scale). Zistili sme, že 1) AMT má vysokú reliabilitu (ICC v rozmedzí 0,985 - 1), 2) vnútorná konzistencia AMT (Cronbachova alfa) sa pohybuje v rozmedzí $0,590-0,787,3)$ neboli zistené žiadne korelácie medzi položkami mapujúcimi teóriu mysle v AMT, IMT a BES, 4) dievčatá skórovali signifikantne lepšie ako chlapci v úlohách teórie mysle v AMT a 5) deti nad 12 rokov signifikantne lepšie skórovali v úlohách teórie mysle v AMT ako mladšie deti. Môžeme konštatovat', že slovenská verzia AMT spíňa psychometrické štandardy a môže byt' používaná $\mathrm{v}$ praxi na mapovanie teórie mysle $\mathrm{u}$ detí. 